Myrtia, no 36 (2021), 222-223

\title{
Lucretius' Corpse Tree: A Botanical Note
}

\author{
Lee Fratantuono* \\ Maynooth University
}

One of the more mysterious features of the natural world mentioned by Lucretius in the last book of his De Rerum Natura is a noisome, deadly arbos on Mount Helicon:

\author{
est etiam magnis Heliconis montibus arbos \\ floris odore hominem taetro consueta necare (VI, 786-787) ${ }^{1}$
}

Commentators on this passage struggle to identify the taxonomy of this arborial horror, if indeed Lucretius had any particular tree in mind. John Godwin notes: "No other ancient author refers specifically to this tree on Mt Helicon ..." 2 The magisterial commentary of Cyril Bailey observes briefly that "it is not easy to identify this tree or the legend," 3 with reference to similarly hazardous plants cited by (Ps.-?) Dicaearchus (where the locus is Mount Pelion), ${ }^{4}$ Pliny the Elder, ${ }^{5}$ and Plutarch. ${ }^{6}$ But none of these parallel botanical references offer much help in identifying Lucretius' Heliconis arbos; at most they offer additional examples of arcane ancient lore about dangerous, potentially deadly trees and flowers.

Lucretius does not describe the appearance of his deadly arbos, but he does localize his hazard: the perilous plant is associated with (not to say native to) Mount Helicon. The Boeotian height had intimate associations with the Muses, ${ }^{7}$ and consequently some scholars have attempted to offer metaliterary readings to explicate the seemingly incongruous presence of a veritable corpse tree on the storied poetic heights. ${ }^{8}$ Would-be classical taxonomists would seem to be limited to consideration of the plants of Helicon, none of which remotely fit Lucretius' eerie description of the malodorous phenomenon. In short, there would seem to be nothing on Helicon then or certainly now that accords with Lucretius' tantalizingly brief note.

But it is likely that there was a true botanical explanation for Lucretius' identification of a noisome plant with the Muses' mount. The poet may have been referencing the ladder-like spirals of what moderns identify as the Helicodiceros muscivorus, an ornamental plant of the arum family native to Sardinia, Corsica, and the Balearic Islands commonly referred to as the "dead horse lily." One writer has said of this plant, "... it was the most fiendish plant I know, the sort of thing Beelzebub might pluck to make a bouquet for his mother-in-law." "The flowers of Helicodiceros smell like rotting flesh (putrescine and cadaverine the apparent culprits), and they attract blow flies as unwitting pollinators. Helicodiceros is related to the

*Dirección para correspondencia: Department of Ancient Classics, Maynooth University, Maynooth, Co. Kildale, Ireland. Email: Lee.Fratantuono@mu.ie

1 All quotes from Lucretius are taken from M. Deufert, ed., 2019.

2 J. Godwin, 1991, p. 150.

${ }^{3}$ C. Bailey, 1947 (corrected reprint, 1949), p. 1674.

${ }^{4}$ Fr. 60 Müller (FGH II, p. 261). The text from. Codd. Gudianus and Parisinus attributed to Dicaearchus by Müller is not so assigned in the later editions of, e.g., David C. Mirhady, 2001, pp. 1-142.

${ }^{5}$ Pliny the Elder, Naturalis Historia XVI, 50-51, of the taxus/smilax, on which see further J. André, 1962, p. 116.

${ }^{6}$ Plutarch, Sympos. III, 1.647 ff., with considerable botanical lore, notably about the harmful effects occasioned by sleeping under certain plants. In both Plutarch and Pliny, the dangerous tree is the yew. Theophrastus (Hist. Plant. III, 3.1) does associate the yew with mountains, though not with Helicon or any other particular height. Most parts of the yew are poisonous. Cf. Pliny XVII, 89, where the shadow of the walnut is allegedly dangerous (with no mention of its odor).

7 For the Muses and Helicon note M. L. West, 1966, p. 152.

${ }^{8}$ So L. Fratantuono, 2015, pp. 445-446; cf. also R. Melville, 1997, p. 271 (with comparison of Virgil, Eclogue 10.76 (of the gravis umbra of the juniper), who wonders if Lucretius is making a polemical argument.

${ }^{9}$ E. A. Bowles in his 1914 botanical miscellany My Garden in Spring (quoted in D. Bown, 2000, p. 131). 
Lee Fratantuono

Lucretius' Corpse Tree: A Botanical Note

Dracunculus vulgaris that is endemic to the Balkans and native to Greece, the open spathe of which is usually marked by a noisome odor. Dracunculus and Helicodiceros have been labeled "the most spectacular of the European aroids." 10 Whatever the Romans of Lucretius' day called them, they would have known the foul-smelling aroids, both from the eastern Mediterranean and from the west (Sardinia, Corsica, etc.). Yew trees may be poisonous, but for plants associated with foul odors, few can compare with certain infamously noisome aroids.

Helicodiceros was so named after the spiral shape of the twisted basal divisions of its leaves, which form a helix. The spiral shape of the foul-smelling flowers of the plant likely occasioned the poet's natural enough association of helix with Helicon. The fact that the plant in question is not to be found on the famous Boeotian mountain was of little concern to Lucretius (if indeed he was even aware of its absence); noisome aroids were known in the Balkans and the Aegean islands. The connection of the helix of the plant with the similarly named Heliconian height was enough to permit the striking image of a corpse tree on the Muse's mount. ${ }^{11}$ Lucretius may well have had metaliterary reasons for his introduction of Helicon into his catalogue of baleful botanical phenomena. Noisome aroids like Helicodiceros allowed for a brilliant botanical play on words, whereby the poet could reference an all too real plant of carrion-like odor, whose helix gave natural rise to associations with Helicon. A Linnaean moment for Lucretius.

\section{Bibliography}

J. André, ed., 1962, Pline l'ancien, Histoire Naturelle, Livre XVI, Paris.

C. Bailey, ed., 1947Titi Lucreti Cari De Rerum Natura Libri Sex, Volume III, Oxford (corrected reprint, 1949).

D. Bown, 2000, Aroids: Plants of the Arum Family (Second Edition), Portland, Oregon.

P. C. Boyce, 1994, “The Genera Drancunculus and Helicodiceros,” Thaiszia 4, pp. 175-182.

M. Deufert, ed., 2019, Titus Lucretius Carus: De Rerum Natura Libri VI, Berlin-Boston.

L. Fratantuono, 2015, A Reading of Lucretius' De Rerum Natura, Lanham, Maryland.

J. Godwin, 1991, Lucretius: De Rerum Natura VI, Warminster.

R. Melville, 1997, Lucretius: On the Nature of the Universe, Oxford.

D. C. Mirhady, ed., 2000 = W. Fortenbaugh, and E. Schütrumpf, E., eds., Dicaearchus of Messana: Text, Translation, and Discussion (Rutgers University Studies in Classical Humanities, Volume 10), Oxford-London.

M. L. West, 1966, Hesiod: Theogony, Oxford.

10 So Peter C. Boyce, 1994, p. 175.

11 The connection of helix and Helicon is rooted in the physical appearance of the plant; the fact that Helicodiceros has been called the "dead horse lily" because of its rotting carcass odor is a modern, popular convention unknown to Lucretius and with no connection to Hippocrene or any equine lore associated with Helicon. 